\title{
The Contradictions of Gay Tele-Visibility: A ReAction to Gamson
}

\author{
TORI BARNES-BRUS \\ University of Kansas
}

As the 2004 Clark Lecturer at the University of Kansas, Joshua Gamson delivered an accessible and provocative discussion regarding the "gaying of straight men" in the mainstream media. Gamson's lecture addressed the recent media hits "Queer Eye for the Straight Guy" and "Boy Meets Boy" as a means to discuss the new "Gay Tele-Visibility." Like the experience of most marginalized groups, the depiction of homosexuality on television has a torrid past. Suffering from a lack of cultural visibility, cast as villains or ill, depicted as full of self-hate, and as sexual predators, media representation of gays, lesbians and trans-gender individuals meant that organizing for basic rights was difficult at best. While these are no longer the primary depictions of gay men, Gamson's point in this piece is to illustrate that cultural visibility is not without its problems. The celebration of gayness in television in recent years is certainly preferable to being cast as demons, yet television prompts the question "If heterosexuality depends in part on its opposite, and homosexual difference is no longer so reliable, what happens to the straight man and his supposed superiority?" (Gamson, 2005:5) The answer resides in the "difference-game" where determining the sexuality of characters, real or fiction, is the key theme of the show. The answer to the difference game lies in the characterization of gay men as master consumers and instructors of upper middle class status. This "difference," argues Gamson is celebrated by current television programs while simultaneously "normalizing" a particular segment of the gay population. Gay tele-visibility, defined as the presence of gay men/char- 
acters on TV, may be on the upswing, yet lesbians are nearly nonexistent. The production process, dependant on formulaic genders and continual re-production reinforces stereotypes and perpetuates a sexual dichotomy.

Gamson's analysis emphasizes television's depiction of gay men as master consumers. For example, in Bravo's Queer Eye for the Straight Guy, heterosexual men benefit from the "expertise" of homosexual men in areas such as grooming, culture, fashion, and design. The heterosexual men become more hetero, more lovable by the women in their lives. At the same time, Bravo's Boy Meets Boy reality dating game show attempts to find a suitable mate for a gay contestant. Of course, the "catch" is that some of the suitors are straight, thus the participants repeatedly play out this difference-normal game. While homosexual intimacy may be represented, it is downplayed as the young contestant is depicted as a "gender-normal seeker of monogamous love relationships and middle class domesticity" (Gamson 2005: PG). While this is may be the script for gay men, no similar shows exist to help lesbian women find their life partner. Gay tele-visibility exists for gay men as they have something to offer heterosexual men. Heterosexual men, according to Gamson's analysis, are rewarded for being a bit more gay, which they can accomplish primarily through consumption. Even with Bravo's new show Queer Eye for the Straight Girl, which features one lesbian and three gay men, lesbians are not depicted as gender normal or as truly experts for straight women. Gay tele-visibility continues to be about male tele-visibility. Gamson readily points to the social class component of these types of shows as the gay men depicted are credible, in part, because they easily represent middle or upper-middle class lifestyles.

Homosexuality obviously intersects with gender and social class. As cultural depictions of working class masculinity are increasingly negative, the bolstering of heterosexual, middle-class masculinity with fashion, culture, and sensitivity is supported by shows such as Queer Eye. Indeed, responses to Gamson's lecture on the University of Kansas campus pointed to this very stereotyping. Self-identified gay students expressed their resentment at the seemingly universal classification of gay men as middle-class 
consumers like the Fab 5. While normalizing may be one way to encourage societal acceptance of marginalized groups, particularly homosexuality, this "normalizing" occurs for a small portion of the gay community, and it too has consequences.

Thus, Gamson's analysis clearly recognizes the limitations of this massive explosion of homosexuality on television, illustrating that the boundaries of acceptable behavior for gay "characters" are still rather strictly drawn. Rarely, if ever, do we see homosexual men engaged in positive or loving relationship and certainly, gay men are not frequently shown in intimate settings. Heteronormativity is still maintained as homosexual intimacy is unacceptable. Queer Eye for the Straight Guy shows the heterosexual men embracing the gay Fab 5 after their transformation, yet viewers are left with no knowledge or evidence that the Fab 5 themselves engage in any sort of love-relationship.

Gay visibility on television and the continued framing of gayness as "normal" in the sense that middle and upper middle class gay men are looking for the "traditional" life partner, class standing and domesticity is certainly preferable to past stereotypes, yet these depictions, too, perpetuate superficial categorizing of homosexuality. The "acceptance" of gayness on television is more about TV. and market segments than about gayness. Ultimately Gamson argues that the normalizing of gayness is problematic because the new gay cultural visibility minimizes the liberalist traditions that celebrated nonconformity and social transformation. Gender, class, and various other social norms are upheld by the new gay visibility. Queer scholars such as Seidman argue that the liberalist tradition of homosexuality emphasizes the sexual freedom and challenges the mainstream ideas of family and coupling. New gay televisibility emphasizes normalcy rather than the blurring of boundaries surrounding what is normal.

All of this indicates the proliferation of stereotypes. A larger question for media scholars and society alike relates to the purpose of television: Should television perpetuate stereotypes or attempt to represent reality? As a social constructionist, I realize that there is not "one" reality out there, yet I am continually concerned with the perpetuation of stereotypes such as these in the 
media. While Kellner (2001) encourages media literacy- teaching our children to "read" media with all of it's contradictory and implicit meanings, it seems that we should also set higher standards for media industries. Gamson argues that the political economy of the television industry, with its attempts to minimize risks and reproduce the things that work, has a great deal to do with the perpetuation of gender and sexual stereotypes. Particular genres like talk shows and reality TV are more conducive to introducing homosexuality into the mainstream, yet these shows also exploit society's understandings of what it means to be gay. Gamson argues that we should not look to television to challenge norms about sexuality, social class, gender and consumption. The discussions presented by the mainstream media about differences, real or perceived, between straight and gay people are couched in TV's strict formulas. While this may be true, the average American spends nearly three hours a day watching television (Croteau and Hoynes 2000: 4-5). Various "readings" of these characters result, yet dominant messages perpetuate existing stereotypes. Visibility may be rising, thus increasing cultural tolerance, but only on a superficial level given producers' adherence to strict formulas with established success records. Fitting characters and television shows into existing genres perpetuates the dichotomy between homosexuals and heterosexuals.

Classroom discussions with college students indicate that while they feel more "accepting" of alternate lifestyles, most of them still base their first impressions of others on stereotypes coming from television. Discussions of sexuality inevitably turn to the cornerstone shows such as Will and Grace and Ellen. Gamson's argument that the proliferation of gay-centered television shows should not be uncritically celebrated is particularly important given the media industries' continued reproduction of existing stereotypes. Rooted in an institution reluctant to take "risks," re-producing "winners" like Queer Eye or incorporating a "token" homosexual within a conventional show allows the mainstream television producers to offer the semblance of diversity and sensitivity to issues of sexuality without challenging the broader gendered social structure. 


\section{References}

Croteau, D. and W. Hoynes. 2000. Media Society: Industries, Images and Audiences. Second Edition. Thousand Oaks, CA: Pine Forge Press.

Kellner, Douglas. 2001 [1995]. Media Culture: Cultural Studies, Identity and Politics Between the Modern and Postmodern. London: Routledge. 